Universidade Tecnológica Federal do Paraná - UTFPR

Campus Ponta Grossa - Paraná - Brasil

ISSN: 1981-3686/v. 05, suplemento: p. 398-407, 2011

D.O.I: $10.3895 / \mathrm{S} 1981-36862011000100003 \mathrm{~S} 1$
Revista Brasileira de Tecnologia

Agroindustrial

\title{
AVALIAÇÃO DE DETERGENTES E ULTRA-SOM PARA ISOLAMENTO DE DNA GENÔMICO DE BACTÉRIAS DE INTERESSE EM ALIMENTOS
}

\section{DETERGENTS AND ULTRASOUND EVALUATION FOR GENOMIC DNA ISOLATION OF FOOD BACTERIAS}

\author{
Robson Rodrigo Miranda ${ }^{1}$; Francielli Casanova Monteiro $^{2}$; Sheila Boreiko ${ }^{3}$ Juliana Vitória Messias \\ Bittencourt $^{4}$ \\ 1, 2, 3,4 Universidade Tecnológica Federal do Paraná - UTFPR - Ponta Grossa - Brasil \\ robsonrm18@hotmail.com
}

\section{Resumo}

As Doenças Transmitidas por Alimentos (DTA) constituem uma preocupação mundial à saúde pública, pois são responsáveis pela causa de várias doenças bacterianas letais quando não diagnosticadas e tratadas a tempo. As bactérias são classificadas em Gram-positivas e Gramnegativas, que se diferenciam através da composição da parede celular, sendo este aspecto é fator essencial para escolha do método de lise celular, que podem ser classificados em enzimáticos, químicos, não-mecânicos e mecânicos. Atualmente existe a grande necessidade de se obter técnicas eficientes para obtenção de DNA genômico de qualidade em termos de quantidade e purificação. Devido a isso, o presente trabalho tem por objetivo avaliar o uso de metodologias para isolamento de DNA genômico cepas de bactérias Ácido-Láticas (BAL), Salmonella sp. e Bacillus cereus com diferentes tempos de cultivo. Os métodos de extração utilizaram diferentes tipos de detergentes $e$ ultra-som para a lise celular, a qualidade do DNA genômico total isolado foi verificada via gel de agarose. O resultado demonstrou que as culturas novas (36h) em meio líquido foram as que apresentaram DNA de melhor qualidade para o auxílio da quebra da parede o aparelho de ultrasom foi o que melhor permitiu o isolamento do DNA bacteriano, além de destacar que os métodos de isolamento de DNA para microrganismos são espécie-específico. Portanto antes de iniciar os trabalhos com um determinado microrganismo há necessidade de determinar qual o detergente mais adequado e também o método de extração mais eficiente para rompimento da parede celular microbiana.

Palavras-chave: microrganismos; parede celular; isolamento de DNA.

\section{Introdução}

A produção de alimentos saudáveis demanda de diversas etapas para garantir a qualidade nutricional e higiênico-sanitária dos produtos, prevenindo a proliferação de doenças, algumas até letais ao consumidor quando não diagnosticadas e tratadas a tempo. A Doença Transmitida por Alimentos (DTA) é uma síndrome ocasionada pelo consumo de alimentos e/ou água que possuem 
agentes etiológicos patogênicos (químicos, biológicos ou físicos) em quantidade suficiente para comprometer a saúde do consumidor, individualmente ou em grupo (RODRIGUES et al., 2010).

Registros epidemiológicos mundiais indicam a importância das (DTAs) como a principal causadora de doenças bacterianas de origem alimentar, no homem, o qual se infecta mediante a ingestão de alimentos contaminados (LINDER, 2002). Assim a verificação da ausência ou presença de bactérias patogênicas é indispensável, para garantir um alimento apto para o consumo (RODRIGUES et al., 2011).

As doenças causadas por DTAs constituem uma preocupação mundial à saúde pública. Nos últimos tempos, o caso de doenças transmitidas por alimentos vem crescendo em diversas partes do mundo. Essas ocorrências tem várias razões, incluindo a adaptação microbiana às mudanças nos sistemas de produção de alimentos, transformações nas práticas agropecuárias, no comércio internacional, tecnologia de alimentos, no estilo de vida, nas demandas dos consumidores, mudanças demográficas e no comportamento humano (RODRIGUES et al., 2010).

Um dos critérios mais intuitivos para classificação e identificação das bactérias é através da avaliação da morfologia do microrganismo, que por meio de propriedades tinturiais (método de Gram) é possível considerar se os microrganismos testados pertencem à classe das bactérias Grampositivas ou Gram-negativas (INFORMATIVO CEFAR DE MICROBIOLOGIA, 2006). Este método consiste basicamente, no preparo de um esfregaço de bactérias corado, sucessivamente, com um corante básico relacionado (cristal-violeta) e com uma solução de iodo diluída, submetendo-se, posteriormente a um solvente orgânico. As bactérias descoradas rapidamente pelo solvente são denominadas Gram-negativas, enquanto que as não descorarem são consideradas Gram positivas (WESP, 2003).

A divisão das bactérias Gram-positivas e Gram-negativas, de acordo com a resposta da coloração de Gram é decorrente das diferenças na composição e estrutura da parede celular (NOGUEIRA et al., 2004). A parede celular das Gram-negativas é formada de uma camada fina composta por peptídioglicano, responsável pela sua fragilidade, já nas Gram-positivas, a camada de peptídioglicano é mais espessa, que consequentemente confere sua rigidez. Essa característica faz com que a quebra da parede celular nas gram-positivas ofereça maior dificuldade, acarretando que as técnicas utilizadas para a quebra desta parede sejam muitas vezes trabalhosas e de alto custo, como o emprego de enzimas (ROSA, 2008).

Até o momento, a técnica mais comum de diagnosticar estes microrganismos presentes em alimentos é empregando os métodos convencionais microbiológicos, que apesar de serem mais os baratos, são trabalhosos e demora de vários dias para obtenção do resultado definitivo (FREITAS et al., 2006). Portanto, devido à este tempo ocioso, vem sendo desenvolvido métodos rápidos como o 
diagnóstico molecular com objetivo fornecer uma alternativa de diagnóstico destes microrganismos devido as limitações mencionadas pela técnica convencional microbiológica.

Para extração de DNA podem ser empregados vários procedimentos de rompimento da parede celular em bactérias, que podem ser classificados em métodos enzimáticos, químicos, nãomecânicos e mecânicos. A lise enzimática consiste na digestão da parede microbiana catalisada por enzimas, sendo a lisozima uma enzima que catalisa a clivagem catalítica de polissacarídeos nas paredes celulares protetoras de algumas famílias de bactérias. Este tipo de procedimento pode degradar, ou lisar, as paredes celulares bacterianas, assim facilitando a exposição do DNA (FARENZENA, 2010). Para realizar o rompimento da parede celular utilizando enzimas é necessário analisar o tipo de microrganismo empregado, o tamanho da célula, tolerância e tensões de cisalhamento, gasto de energia, tempo de operação, necessidade de controle de temperatura, rendimento do processo, custo e capital de investimento (MARINELLO, 2009).

O tratamento químico é a utilização de diversos detergentes, sendo o brometo de cetiltrimetilamônio (CTAB) e dodecil sulfato de sódio (SDS) bastante utilizado para auxiliar na liberação de componentes celulares por lise das membranas celulares (REGITANO et al., 2007 e MESQUITA et al., 2001). A adição do detergente além de auxiliar quimicamente na ruptura na liberação dos componentes também é fundamental para desnaturação de proteínas e exposição dos ácidos nucleicos diante do detergente utilizado pelo protocolo (DANTAS, 2011).

Um dos processos não-mecânico é o rompimento da membrana por congelamento ou descongelamento, que consiste na formação intracelular de grandes cristais de gelo que possui a capacidade de perfurar a célula e causa seu total rompimento ou lesioná-la a ponto de formar poros permeáveis à biomolécula-alvo. É um método simples e indicado para o rompimento de parede celular de patógenos, entretanto, é um processo demorado, de custo elevado e inadequado para biomoléculas sensíveis ao congelamento (MARINELLO, 2009).

O método mecânico mais empregado atualmente para rompimento celular é a aplicação do ultra-som ou sonicação, que pode ser utilizado em conjunto com outros tratamentos, nomeadamente tratamento térmico, de pressão e produção combinada de calor e pressão. Os aparelhos geradores de ondas ultra-sonoras que existem são destinados à diversas funções: o banho, preferencialmente empregado para limpeza de material, homogeneização e solubilização, mas entre essas e outras utilidades destaca-se e o rompimento da parede celular. O uso do banho de ultra-som é um processo de baixo custo, simples, sendo constituído por um banho de metal com um ou mais transdutores presos às paredes do tanque, sendo empregado para quebra da parede celular bacteriana (SANTOS et al., 2010 e PIRES, 2006).

O uso de protocolos moleculares tem sido extensivamente aplicado em quase todos os ramos da microbiologia e uma de suas etapas decisivas é o isolamento do DNA bacteriano em quantidade 
e qualidade suficiente para amplificação pela reação em cadeia da polimerase - PCR (NOGUEIRA et al., 2004).

O método via PCR apresenta vantagens como rapidez, além do bom limite de detecção, alta seletividade e potencial, estas vantagens tornam a técnica uma eficiente alternativa aos métodos tradicionais de diagnóstico. Entretanto, o alto custo de investimento tecnológico, a necessidade de aprovação oficial e instruções padronizadas fazem de que este método seja pouco empregado (FREITAS et al., 2006).

Atualmente existe a grande necessidade de se obter técnicas eficientes para obtenção de DNA genômico de qualidade em termos de quantidade e purificação. Devido a isso, o presente trabalho tem por objetivo avaliar o uso de metodologias para isolamento de DNA genômico de cepas de bactérias Ácido-Láticas (BAL), Salmonella sp. e Bacillus cereus, isoladas de diferentes fontes de alimentos.

\section{Material e Métodos}

\section{Amostras de microrganismos}

Foram utilizadas culturas puras de microrganismos isolados de alimentos, as quais, cepas de Bactérias Ácido-Láticas (BAL) e de Salmonella sp relativas aos descartes do Laboratório de Microbiologia da UTFPR. Em outro momento foi testado cepas de Bacillus cereus, respectivo ao estudo em andamento no Laboratório de Microbiologia da UFPR sobre a incidência deste microrganismo em produtos lácteos.

\section{Método de extração}

Os métodos de extração utilizaram diferentes tipos de detergentes e tratamentos para a lise celular. A metodologia foi adaptada a partir do protocolo descrito por Moreira et al., (2010). Os detergentes testados neste trabalho foram brometo de cetiltrimetilamônio CTAB (CTAB 2\%, NaCl 1,4 M, EDTA 20mM, Tris-Cl pH 8100 mM, PVP-polivinilpirrolidona 1\%, 2-mercaptoetanol 0,8\%) e dodecil sulfato de sódio SDS ( $\mathrm{NaCl} 1 \mathrm{M}$; Tris- $\mathrm{HCl}$ pH 8,0 $1 \mathrm{M}$; EDTA 0,5 M pH 8,0; SDS 1\%) (CLEMENTE, 2010). O primeiro teste foi a utilização do detergente CTAB empregando para o auxilio da lise celular o ultra-som, em seguida o outro tratamento foi uso do detergente SDS 
utilizando a enzima proteinase-K. As etapas do protocolo de extração de DNA estão esquematizadas na Figura 1.

Figura 1 - Fluxograma de extração de DNA

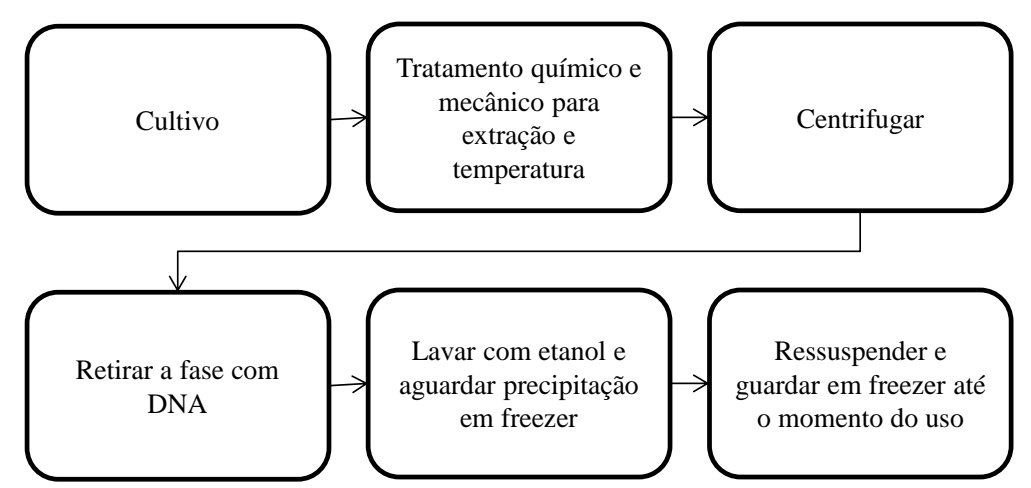

Verificação da qualidade do DNA

Os DNAs isolados foram submetidos à verificação da qualidade, sendo alíquotados $3 \mu 1$ de tampão de carreamento 1x (azul de bromofenol) e $5 \mu 1$ de DNA. A mistura foi aplicada em gel de agarose $1 \%$ em tampão TBE (Tris base, ácido bórico, EDTA) à $70 \mathrm{v}$ por 30 minutos. Esse gel foi corado com brometo de etídio para posterior visualização sob luz ultravioleta (UV).

\section{Resultados e Discussão}

Para os testes de isolamento do DNA foram utilizadas culturas em meio sólido (ágar nutriente) e líquido (caldo nutriente). As culturas em meio líquido foram as que apresentaram DNA de melhor qualidade. Outra característica de grande relevância é que cultivos novos (36h) são os que possibilitam isolamento mais eficiente.

$\mathrm{O}$ isolamento de DNA de boa qualidade de qualquer cultura microbiana é um passo fundamental para o desenvolvimento de qualquer método de análise direta da molécula de ácido desoxirribonucléico, seja para restrição enzimática, seqüenciamento, ou amplificação via PCR (Polimerase Chain Reaction). Para a extração e purificação de ácidos nucleicos, é preciso separá-los com eficiência dos outros componentes celulares. Em relação aos ácidos nucleicos, também é essencial conservar a integridade das moléculas, que devem continuar inalteradas durante o processo de extração, pois as informações contidas tanto no DNA quanto no RNA dependem da sua sequência (LISBÔA, 2011). 
Dentre os detergentes testados para a extração do DNA, o detergente CTAB foi o que apresentou maior eficiência para o isolamento do DNA microbiano das culturas avaliadas, quando comparado ao detergente SDS.

Entre as variáveis testadas, a utilização do ultra-som foi a que melhor permitiu o isolamento do DNA, auxiliando a quebra da parede celular e possibilitando a exposição do ácido nucléico para seu eficiente isolamento. O mecanismo de ação do ultra-som reside no fenômeno conhecido como cavitação, que é a formação e implosão de bolhas que se colidem violentamente, provocando entre outros efeitos a desintegração das células microbianas e expondo o seu conteúdo (PIRES, 2006). Salienta-se o uso de proteinase-K, o qual não se mostrou eficiente para os microrganismos testados.

O protocolo que forneceu o DNA genômico de melhor qualidade apresentou as seguintes etapas: 1) homogeneização em vortex dos tubos de ensaio com a cultura em meio líquido; 2) transferência de 1,5ml da cultura para os tubos de eppendorf; 3) centrifugação por 1 minuto a 12000 rpm; 4) descarte do líquido sobrenadante; 5) adição de 450 1 le CTAB; 6) agitação em vortex para ressuspender o precipitado; 7) agitação em vortex de bandeja por 1 minuto; 8) sonicação por 1

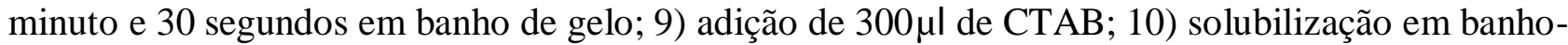
seco por 20 minutos à $65^{\circ} \mathrm{C}$; 11) adição de $750 \mu$ l de clorofórmio; 12) agitação por 5 minutos em vortex de bandeja; 13) centrifugação por 7 minutos à 12000 rpm; 14) transferência do sobrenadante para outro tubo de eppendorf; 15) adição de $750 \mu$ l de clorofórmio; 16) agitação por 5 minutos no vortex de bandeja; 17) centrifugação por 7 minutos à 12000 rpm; 18) transferência do sobrenadante para outro tubo de eppendorf; 19) adição de 2 volumes de etanol $96 \%$ gelado, homogeneizando por inversão suavemente; 20) acomodação dos tubos em freezer à $-20^{\circ} \mathrm{C}$ por 30 minutos; 21) centrifugação por 7 minutos à 12000 rpm e descarte do líquido; 22) adição de $750 \mu$ le etanol 70\% gelado; 23) centrifugação por 7 minutos à 12000 rpm; 24) descarte do líquido; 25) secagem do pellet a temperatura ambiente; 26) ressuspensão do pellet em $50 \mu$ l de água miliq.

Apesar do protocolo ser o mais indicado para os microrganismos testados, a etapa de ultrasom não é indicado para todos. Portanto os resultados evidenciaram que alguns microrganismos são mais susceptíveis ao seu uso do que outros. Por exemplo, Bacillus cereus respondeu positivamente ao uso do equipamento de ultra-som. A Tabela 1 abaixo apresenta a resposta de uso deste equipamento em outros gêneros.

Tabela 1 - Resultado da aplicação do ultra-som para isolamento do DNA

\begin{tabular}{ccc}
\hline Amostras de bactérias & Positivo & Negativo \\
\hline Ácido-Láticas (BAL) & + & - \\
Bacillus cereus & + & \\
Salmonella sp. & & - \\
\hline
\end{tabular}


A aplicação deste protocolo se mostrou eficiente para algumas bactérias. Sendo assim, para os microrganismos pertencentes à classe Gram-positiva, bactérias Ácido-Láticas (BAL) e Bacillus cereus, o protocolo apontou-se recomendável para extração de DNA genômico. Contudo, há necessidade de salientar que o grupo de bactérias Ácido-Láticas (BAL) é bastante heterogêneo. Já as cepas de Salmonella sp., pertencente à classe das bactérias Gram-negativas, o protocolo se mostrou ineficiente.

O Bacillus cereus é formador de esporos, Gram-positiva, comumente encontradas em solos, vegetais e em diversos alimentos processados e crus. Esta bactéria é capaz de produzir toxinas, enterotoxinas, uma potente toxina emética, proteases, hemolisinas e fosfolipases. Está veiculado também aos surtos por intoxicação alimentar, provocando diarréia e emese (GOMES et al. 2004).

Devido a sobrevivência em diferentes temperaturas e valores de $\mathrm{pH}$ resistir à desidratação e irradiação e capacidade aderência às superfícies que contatam alimentos. Os profissionais da área de alimentos encontram dificuldades para eliminar o microrganismo do ambiente industrial (ANDERSSON, 1995 e KOTIRANTA et al., 2000). Este microrganismo é isolado de produtos crus ou processados, como arroz, condimentos, vegetais, produtos cárneos e alguns laticínios. Estas bactérias não são esporulantes, pertencem as Gram-positivas, não móveis e produzem ácido lático como o maior ou o único produto de fermentação da glicose (MARTINS et al., 2006). Esta bactéria é comumente utilizada na indústria de laticínios na elaboração de produtos lácteos fermentados, como queijos e iogurtes (LIMA, 2010). Esta bactéria está amplamente distribuída na natureza, principalmente no leite. Elas são também habitam os tratos digestivo, respiratório superior e urogenital inferior dos animais (HOVE et al., 1999). O grupo é constituído de bastonetes e cocos não esporulados, aeróbios, microaerófilos ou anaeróbios facultativos. São inativas com temperaturas acima de $70^{\circ} \mathrm{C}$ (SALMINEN e VON WRIGHT, 1993).

A divisão de bactérias Gram-positivas e negativas foi demonstrada na Tabela 1, no entanto, esta divisão é quimicamente explicada pelo fato que a parede celular das bactérias Gram-positivas é constituída de uma camada espessa composta por peptídioglicano, já nas Gram-negativas, esta camada é mais fina, o que conseqüentemente confere maior fragilidade. Essa característica faz com que a quebra da parede celular nas Gram-positivas seja mais difícil a qual reflete a ação dos reagentes e métodos físicos que o protocolo apresentado neste trabalho utiliza (ROSA, 2008).

A Salmonella sp. são pequenos bastonetes gram-negativos, não esporulados, que pertencem a família das enterobactérias que podem causar graves infecções gastrointestinais de origem alimentar, o que torna sua presença em alimentos um relevante problema de saúde pública (REIS et al., 2002). Os sintomas predominantes em uma pessoa contaminada pela bactéria são dores abdominais, vômitos, cefaléia, calafrios e forte diarréia (PERESI et al., 1998). 
No cenário das doenças transmitidas por alimentos e apesar do aparecimento de novos microrganismos a Salmonella sp. ocupa o lugar de destaque nas estatísticas epidemiológicas dessas doenças (SANTOS et al., 2003). Em função dos riscos que a Salmonella sp. representa para os consumidores, sua pesquisa em alimentos é de extrema importância. Os produtores de alimentos, assim como os órgãos competentes de fiscalização, não têm medido esforços para garantir a ausência de Salmonella sp. nos alimentos (REIS et al., 2002).

Com o resultado da Tabela 1, para o isolamento de DNA de bactérias Ácido-Láticas (BAL) demonstrou-se que devido à heterogeneidade deste grupo há necessidade de lançar mão da utilização de outros produtos que possibilitem o isolamento de DNA. Pois quando as extrações deste grupo de bactérias não forem possíveis apenas com a utilização de ultra-som pode ser empregados reagentes como a lisozima. Segundo o autor Falcon (2007), esta enzima possui a capacidade de quebrar as membranas externas de diversas espécies bacterianas gram-positivas, com isso destruindo o esqueleto glicano do peptídeoglicano, ou seja, desintegrando a estrutura da parede celular de muitos microrganismos.

\title{
4. Considerações finais
}

Esta pesquisa demonstrou que os métodos de isolamento de DNA para microrganismos são espécie-específico, portanto antes de iniciar os trabalhos com um determinado microrganismo há necessidade de determinar qual o detergente mais adequado e também o protocolo de extração mais eficiente para rompimento da parede celular microbiana. De acordo com os microrganismos testados indica-se o uso do detergente CTAB e utilização do ultra-som.

\begin{abstract}
Foodborne Diseases (FBD) constitute a worldwide public health concern, because they are responsible for several bacterial lethal diseases, if not diagnosed and treated in time. According composition of the cell wall, bacteria are classified in Gram-positive and Gram-negative, this aspect is essential factor to choose cell lysis method, which can be classified in enzymatic, chemical, it can be mechanical or no mechanical method. Currently there is a great need for effective techniques to obtain quality in terms of genomic DNA. Thus, the present study aims to evaluate the use of methodologies for bacteria genomic DNA isolation of. In this study were used strains of Acid Láticas (BAL), Salmonella sp and Bacillus cereus with different time of cultivation. The DNA extraction methods used different types of detergents and ultrasound process for cell lysis, the quality of total genomic DNA isolated was verified by agarose gel. The result showed that new cultures (36 h) in a liquid medium presented DNA of better quality, as well the use of ultrasound apparatus was allowed bacterial DNA isolation IN SOME GENUS, in the light of these results it is possible to conclude that DNA isolation methods for micro-organisms are species-specific. Then before starting the work with a micro-organism there is a need to determine what is the best detergent and also the more efficient extraction method for microbial cell wall disruption.
\end{abstract}

Key-words: micro-organisms, cell wall; DNA isolation. 


\section{Referências}

ANDERSSON, A.; RONNER U.; GRANUM, P. E. What problems does the food industry have the spore-forming pathogens Bacillus cereus and Clostridium perfrigens. International Journal of Food Microbiology, v. 28, n.2, p.145-155, 1995. DOI: 10.1016/0168-1605(95)00053-4

CLEMENTE, M. S. Análise da variação genética de populações de Vochysia pyramidalis e V. tucanorum por AFLP e da composição de ácidos graxos de sementes. São Paulo, 2010. Dissertação (Mestrado em Biociências) Departamento de Botânica - Universidade de São Paulo.

DANTAS, A. C. M. Extração e análise de DNA vegetal. Universidade Federal de Santa Catarina. 2011.

FALCON, R. D. $\beta$-glucano e vitamina C no desempenho produtivo e parâmetros fisiopatológicos em juvenil de tilápia do Nilo: nível de suplementação e tempo de administração. Jaboticabal-SP, 2007. Tese (D Aqüinocultura) Departamento de Pós-graduação em Aqüinocultura - Universidade Estadual Paulista.

FARENZENA, R. Aderência e atividade fibrolítica bacteriana ruminal: efeito do pH e da concentração de carboidratos solúveis. Disponível em <http://w3.ufsm.br/ppgz/conteudo/Defesas/Dissertacoes/RobertaFarenzena.pdf〉. Acesso em 27 jan. 2011.

FREITAS, E. I.; LEMOS, A. A.; MARIN, V. A. Validação de métodos alternativos qualitativos na detecção de patógenos alimentares. Ciência e Saúde Coletiva. v.11, p.1073-1083, 2006. DOI: 10.1590/S1413-81232006000400028

GOMES, L. P.; RODRIGUES, M. M.; SOARES, G.; BARONI, F. A.; SOUZA, M. M. S. Bacillus cereus em amostras de doces industrializados comercializados por ambulantes nos municípios de Seropédica e Itaguaí-RJ. Revista Universidade Rural. v. 24, n.2, p.103-106, 2004.

HOVE, H.; NORGAARD, H.; MORTENSEN, P. B. Lactic acid bacteria and the human gastrointestinal tract. European Journal of Clinical Nutrition, n.53, p.339-350, 1999. DOI: 10.1038/sj.ejcn.1600773

INFORMATIVO CEFAR DE MICROBIOLOGIA. Identificação de microrganismos. Ano III Ed.18, nov./dez. 2006. Disponível em < http://www.cefar.com.br/download/jornal\%2018ed_web.pdf>. Acesso em 06 ago. 2011.

LIMA, C. P. Resistência de bactérias láticas a bacteriófagos isolados na produção de queijos de coalho no Ceará. Fortaleza-CE, 2010. Dissertação (Mestrado em Ciência e Tecnologia de Alimentos) - Pós-Graduação em Ciências e Tecnologia de Alimentos - Universidade Federal do Ceará.

LINDER, C. E. Salmonella spp. em sistema intensivo de criação de peixes tropicais de água doce. Botucatu-SP, 2002. Dissertação (Vigilância Sanitária Animal) - Pós-Graduação de Medicina Veterinária - Universidade Estadual Paulista.

LISBÔA, R. S. Biologia Molecular para iniciantes. Universidade Federal Rural do Rio de Janeiro. 2011.

KOTIRANTA, A.; LOUNATMAA, K.; HAAPASALO, M. Epidemiology and pathogenesis of Bacillus cereus infections. Microbes and Infection, v.2, n.2, p.189-198, 2000. DOI: 10.1016/S1286-4579(00)00269-0

MARINELLO, M. Rompimento celular. Disponível em <http://www.ebah.com.br/rompimento-celular-doca28419.html>. Acesso em 27 jan. 2011.

MARTINS, A. D. O.; MENDONÇA, R. C. S.; SILVA, D. L.; RAMOS, M. S.; MARTINS, M. C.; DONZELE, J. L.; ANDRADE, N. J. Resistência de bactérias lácticas, isoladas de fezes de suínos e sua capacidade antagônica frente a microrganismos indicadores. Revista de Ciências Agroveterinárias. Lages, v.5, n.1, p. 53-59, 2006.

MESQUITA, R. A.; ANZAI, E. K.; OLIVEIRA, R. N.; NUNES, F. D. Avaliação de três métodos de extração de DNA de material parafinado para amplificação de DNA genômico pela técnica da PCR. Pesquisa Odontológica Brasileira, v. 15 , n. 4 , p. 314-319, out./dez. 2001.

MOREIRA, M., NOSCHANG, J., NEIVA, I.F., CARVALHO, Y., HIGUTI, I.H., VICENTE, V.A. Methological variations in the isolation of genomic from Streptococcus bactéria. Brazilian Archives of Biology and Technology. v.53, n.4, p.845-849, 2010. DOI: 10.1590/S1516-89132010000400013 
NOGUEIRA, M. A. C.; MOMESSO, S. A. C.; MACHADO, D. L. R.; ALMEIDA, G. T. M.; ROSSIT, B. R. A. Desempenho de kits comerciais e protocolos laboratoriais para a extração de DNA genômico bacteriano. Revista Panamericana de Infectologia. v. 6, n.2, 2004.

PERESI, J. T. M.; ALMEIDA, I. A. Z. C; LIMA, S. I.; MARQUES, D. F.; RODRIGUES, E. C. A.; FERNANDES, S. A.; GELLI, D. S.; IRINO, K. Surtos de enfermidades transmitidas por alimentos causados por Salmonella Enteritidis. Revista Saúde Pública. v. 32, n. 5, p.477-183, 1998. DOI: 10.1590/S0034-89101998000500011

PIRES, C. C. Efeitos das radiações gama e ultra-sônica em suco de laranja contaminado por Alicyclobacillus acidoterrestris. Piracicaba-SP, 2006. Dissertação (Mestrado em Ciência e Tecnologia em Alimentos) - Departamento de Ciência e Tecnologia de Alimentos - Universidade de São Paulo.

REGitANO, de A. C. L.; NICIURA, M. C. S.; IBELLI, G. M. A.; GOUVEIA, de S. J. J. Protocolo de biologia molecular aplicada à produção animal. Disponível em

<http://www.cppse.embrapa.br/080servicos/070publicacaogratuita/e-book/LivroProtMol.pdf〉. Acesso em 29 jan. 2011.

REIS R. B.; MAMIZUKA E. M.; FRANCO, B. D. G. M. Padronização de um teste imunoenzimático para detecção de Salmonella em alimentos. Revista Ciência e Tecnologia em Alimentos. v.22, n.2, p.105- 110, 2002. DOI: 10.1590/S0101-20612002000200001

RODRIGUeS, E.; GroOtenbOeR, C. S.; Mello, S. C. R. P.; CAStAGnA, A. A. Manual de Boas Práticas de Fabricação. Niterói-RJ. 2010.

RODRIGUES, M. X.; BITTENCOURT, J. V. M.; PINHEIRO, K. H. Aplicação de polymerase chain reaction (PCR) na detecção de bactérias patogênicas em alimentos. Ponta Grossa-PR. 2011.

ROSA, D. Método rápido de extração de DNA de bactérias. Disponível em < http://www.scielo.br/pdf/sp/v34n3/11.pdf>. Acesso em 27 jan. 2011.

SANTOS, A. F.; VIZEU, D. M.; DESTRO, M. T.; B.D.G.M.; FRANCO, B. D. G. M.; LANDGRAF, M. Determinação da dose de radiação gama para reduzir a população de Salmonella spp em carne de frango. Ciência e Tecnologia em Alimentos. v.23, n.2, p.200-205, 2003.

SANTOS, A.; LOURENÇO, D.; FERREIRA, S.; PITA, N.; CABETE, A. Ondas de ultra-sons. Disponível em < http://www.esac.pt/noronha/pga/0910/trabalho_mod2/Ultra_sons_PGA_turma_2.pdf>. Acesso em 28 jan. 2011.

WESP, C. L. Teste de Gram. Porto Alegre-RS, 2003. Disponível em

<http://www.ufrgs.br/agrofitossan/fit35/carolineGram.pdf>. Acesso em 21 jul. 2011.

Trabalho selecionado para apresentação oral durante a VIII SETAL- Semana de Tecnologia de Alimentos- Câmpus Ponta Grossa- Universidade Tecnológica Federal do Paraná- 01 a 03 de junho de 2011. Suplemento especial da RBTA. 